\title{
OPTIMIZATION OF THE THERMAL TRANSFER PROCESSES FOR ELEMENTS APPLIED ON GARMENT PRODUCTS
}

\author{
Valentina Bulgaru*, ORCID: 0000-0003-3105-4012, \\ Marcela Irovan, ORCID: 0000-0001-6231-7378, Oxana Trocin \\ Technical University of Moldova, 168, Stefan cel Mare Boulevard., MD-2004, Chisinau, Republic of Moldova \\ ${ }^{*}$ Corresponding author: Valentina Bulgaru, valentina.bulgaru@fiu.utm.md
}

Received: 09. 24. 2021

Accepted: 11. 25. 2021

\begin{abstract}
The main objective of the paper is optimization of the process of thermal transfer in order to obtain - with minimum number of tests and maximum precision - a high adhesion degree of stencils applied to the garments. The major factors affecting the thermal transfer processes are: temperature, pressure, time, and the characteristics of the textile (fiber composition, finishing, structure of the face surface, etc.). The problem is current for most companies that produce clothing for sports and outdoor activities. This category of products is quite complex due to processing technology, combinations of various textile components, cutout components and most importantly the informative and decorative elements applied through thermal transfer process. To optimize the thermal transfer process, a series of experiments with a central rotating compound were applied. Analysis and Interpretation of the results showed that the pressing time is the most important factor of the adhesion of the thermal transfer to the textile material and its ulterior resistance to washing.
\end{abstract}

Keywords: central rotating compound plan, design of experiment, optimization, sportswear, thermal transfer.

Rezumat. Obiectivul principal al lucrării constă în optimizarea procesului de transfer termic pentru a obține - cu un număr minim de teste și precizie maximă - un grad ridicat de aderență a șabloanelor aplicate pe articole de îmbrăcăminte. Factorii majori care afectează procesele de transfer termic sunt: temperatura, presiunea, timpul și caracteristicile materialului textil (compoziția fibrelor, finisarea, structura suprafeței feței etc.). Problema este actuală pentru majoritatea companiilor care produc îmbrăcăminte pentru sport și activități în aer liber. Această categorie de produse este complexă datorită tehnologiei de prelucrare, combinațiilor de diverse componente textile, componente decupate și cel mai important, a elementelor informative și decorative aplicate prin procesul de transfer termic. Pentru a optimiza procesul de transfer termic, s-au aplicat o serie de experimente cu un compus rotativ central. Analiza și interpretarea rezultatelor au arătat că timpul de presare este cel mai important factor al aderenței transferului termic la materialul textil și al rezistenței sale ulterioare la spălare.

Cuvinte cheie: plan compus rotativ central, proiectarea experimentului, optimizare, îmbrăcăminte sport, transfer termic. 


\section{Introduction}

Nowadays clothing for sports and outdoor activities is a fairly important segment of global clothing production. In terms of complexity, performance, design and comfort that it has to provide, it exceeds the requirements for the ordinary clothing [1]. Sportswear and clothing for outdoor activities must ensure the necessary comfort while practicing sports and they have to be resistant to a variety of external factors. This could be achieved through the right choice of materials and design. The textile materials used for sportswear have undergone a significant evolution of performance in terms of elasticity and local pressures on the human body, antibacterial properties and ensuring thermal comfort [2 - 5].

In the same way the attached elements carrying a manufacturer's logo, trademark or other information applied, in most cases, through thermal transfer, they must be resistant to repeated stress by stretching, bending, abrasion and repeated washing.

Heat transfer printing means application at a high temperature $\left(120-190^{\circ} \mathrm{C}\right)$ of a design (drawings, images, inscriptions, etc.) on various target surfaces using special intermediate materials (thermal transfer film/foil or special paper for thermal transfer) [6,7]. The image is applied to special paper or film and is transferred to the target surface using a thermal press.

The use of heat transfer has a number of advantages over other printing technologies:

$\checkmark$ the transfer of very fine lines and small details, which allows the image to be more precise and natural;

$\checkmark$ unlike sublimation and direct printing, thermal transfer printing allows the decoration of fully finished products (with zippers, buttons, applied pockets, with prominent parts of the products); color images with photographic quality can be applied, which is impossible to achieve with screen printing, and the color brightness is much higher than when using sublimation printing;

$\checkmark$ heat transfer allows you to print images in large quantities and apply them to products as needed, regardless of the material - this allows you to change the product model, color and materials;

$\checkmark$ the main advantage of heat transfer over other printing technologies is the speed of order execution.

Effects such as glitter, hologram, or reflective can be easily obtained by thermal transfer [8].

The review [9] presents developments in transfer printing and the various factors that affect transfer printed product quality besides dyes, and how these factors affect the transfer printing process. In order to obtain a qualitative result, the optimal values of the three technological parameters must be established and later maintained. Those parameters are pressure, temperature and time of exposure to temperature under pressure $[10,11]$.

With the implementation of new high-performance fibers in sportswear textiles, methods and techniques for finishing them were developed and proposed, including theat transfer printing and application of various emblems, logos etc. [12, 13].

Following the analysis of the experience of CSM Uniform regarding the technologies applied for the manufacturing of clothing (Montura brand) and experience in manufacturing clothes for active sports, it was found that the problem of obtaining the quality that meets the requirements of the beneficiaries and current standards requires constant changing of thermal transfer parameters, thus involving of specialists. Starting from this aspect, the 
purpose of this paper was to study and determine how the quality of the print by heat transfer printing depends on the fibrous composition of the textile material and to establish the optimal parameters to ensure a high quality of the print.

\section{Research methodology}

\subsection{Materials included in the study}

The garments manufactured at CSM Uniform (for Montura brand) are made of the following textiles: knitwear, synthetic fibers, mainly polyamide (PA) and polyester (PES), as well as in various proportions of PA and PES mixture with elastane. Three types of textiles were selected for the research:

1) Membrane fabric, article TS442 in green color, made of $100 \%$ polyamide fibers, produced with GORE-TEX ${ }^{\circledR}$ ACTIVE technology. Properties: waterproof (up to 28,000 $\mathrm{mm}$ of water), made of wind resistant material that allows air circulation (RET <3.5).

2) Fabric, article TS286 in black color, made of $86 \%$ polyamide and $14 \%$ elastane. Properties: density - $137 \mathrm{~g} / \mathrm{m}^{2}$, elastic, characterized by high wear resistance and waterrepellent DWR treatment.

3) Knitwear, article JS567, in blue color, made of $59 \%$ polyimide and $41 \%$ elastane, produced by EUROJERSEY, Sensitive ${ }^{\circledR}$ Fabrics. Properties: provides high protection against UV rays (UPF50) due to SUN-BLOCK treatment of the fabric, anti-pilling.

As an element applied through the thermal transfer process was the Company Logo (EA5) which was cut from black reflective and fluorescent film, made by SISER [14].

\subsection{Experimental research}

The experimental research is aimed at:

1) establishing the influence of thermal transfer process's technological parameters like temperature, pressure and time on the output parameter values (adhesion of the thermal transfer film with the brand logo on it to the textile material after 5 washing for 3 types of textile material frequently used in sportswear).

2) establishing mathematical models for the thermal transfer process on 3 types of textile materials with different composition;

3) optimization of the heat transfer process.

The research was carried out on the basis of a series of experiments according to the central composite rotational design of the second order with three independent variables [15]:

$\mathrm{x}$, - represents pressing temperature value, ${ }^{\circ} \mathrm{C}$;

$x_{2}$ - represents pressure value, atm.;

$\mathrm{x}_{3}$ - represents pressing time value, $\mathrm{s}$.

The zero level, the variation step, the variation limits and the coding of the parameters are presented in "Table 1".

The real values of physical parameters of the thermal transfer process are temperature, pressure and pressing time.

They were selected according to the recommendations of CSM Uniform specialists, and the variation intervals were based on recommendations from the literature. 


\section{Experimental range and levels of independent variables used in central composite rotational design.}

\begin{tabular}{lccccc}
\hline Independent variables & \multicolumn{5}{c}{ Range and levels } \\
\cline { 2 - 6 } & $-\alpha(1,68)$ & -1 & 0 & +1 & $+\alpha(1,68)$ \\
\hline Temperature, ${ }^{\circ} \mathrm{C}$ & 150 & 155 & 165 & 175 & 185 \\
\hline Pressure, atm & 2 & 3 & 4 & 5 & 6 \\
\hline Time, $\mathrm{s}$ & 3 & 10 & 20 & 30 & 35 \\
\hline
\end{tabular}

The purpose is to obtain a print with maximum wear-resistance throughout the life span of the clothing products; the measured output parameter is the adhesion after five washings. Its maximum value is the 4th degree according to the scale below.

\subsection{Method of performing the heat transfer}

The heat transfer was performed with the MACPI automatic press, model 346.37 - 9222 series 127600. For each experiment according to the design of experiments, 5 samples of textile material with dimensions of $149 \times 210 \mathrm{~mm}$ were cut. The foil for thermal transfer with the logo of the Montura brand with dimensions of $30 \times 30 \mathrm{~mm}$ was applied to them.

\subsection{Method of determining the print adhesion}

The level of adhesion was determined by testing after 5 consecutive washings of the textile materials samples which were subjected to thermal transfer process. The washings were performed under the following conditions: the first washing was performed after at least 10 hours from the time of application of the thermal transfer, other 4 times were each performed every 24 hours.

The washings were performed in the BOSCH WLX161610E washing machine, temperature was set to $40^{\circ} \mathrm{C}$, program was set to synthetic materials, duration of a washing cycle was set to 1 hour and 30 minutes. Detergent used: Ariel 3 in 1 universal, 1 capsule per washing cycle. The experimental samples were dried on a special drying rack at $21-22^{\circ} \mathrm{C}$.

Adhesion was determined organoleptically by manual detachment and assignment of points / degrees of resistance according to the scale:

1- detaches with minimal effort;

2 - satisfactory grip, peels off with greater effort;

3 - good adhesion, detaches with a significant effort;

4 - excellent adhesion, does not peel off.

\section{Results and discussions}

A design of experiments was made for the realization of experimental variants. Pressing temperature $\left({ }^{\circ} \mathrm{C}\right)$; pressure $(\mathrm{atm})$; time $(\mathrm{s})$ were determined for each variant. The experimental values were processed using the OPTEX software [16].

The computer calculates the coefficient values for the linear and quadratic part of a mathematical model of the formula for a three-variable model $y=b_{0}+b_{i} x_{i}+b_{2} x_{2}+b_{3} x_{3}+b_{12} x_{1} x_{2}$ $+b_{13} x_{1} x_{3}+b_{23} x_{2} x_{3}+b_{11} x_{1}^{2}+b_{22} x_{2}^{2}+b_{33} x_{3}^{2}$

The program checks the significance of the coefficients through Student test and it checks the adequacy of the model through the Fisher - Snedecor test. It was also necessary to further verify the adequacy through the Adler method by calculating the percentage of differences between the measured values and the calculated result, all this information being provided by the program in accessible forms, which can be commented and interpreted by the researcher. Optimization of the print adhesion parameter achieved during the heat 
transfer process was performed by analyzing the isocurves resulting from the graphical representation of mathematical models. The graphic representations were made both threedimensional and as a graph in order to obtain, on the one hand the geometric body that mathematically represents the studied process and on the other hand, the representations in the graph allowed to obtain curves of form $y=f\left(x_{1}, x_{3}\right)$ and $y=f\left(x_{2}, x_{3}\right)$ used for the technological discussion and the choice of the supposedly optimal or sub-optimal values of the result - the adhesion of the print depending on the temperature, pressure and pressing time. "Table 2" presents the data obtained for the assortment - knitwear from 59\% PA + 41\% EA.

Table 2

Central composite rotational design (CCRD) for optimization of three variables in experimental values for heat transfer on knitwear from 59\% PA + 41\% EA

\begin{tabular}{lcccccccc}
\hline Nr. & $X_{1}$ cod & $X_{2}$ cod & $X_{3}$ cod & $X_{1}$ real & $X_{2}$ real & $X_{3}$ real & Ymeasur. & Ycalcul. \\
\hline 1 & +1 & +1 & +1 & 175 & 5 & 30 & 4 & 4,157 \\
\hline 2 & -1 & +1 & +1 & 155 & 5 & 30 & 4 & 4,011 \\
\hline 3 & +1 & -1 & +1 & 175 & 3 & 30 & 4 & 4,011 \\
\hline 4 & -1 & -1 & +1 & 155 & 3 & 30 & 4 & 4,364 \\
\hline 5 & +1 & +1 & -1 & 175 & 5 & 10 & 2 & 2,308 \\
\hline 6 & -1 & +1 & -1 & 155 & 5 & 10 & 1 & 1,661 \\
\hline 8 & +1 & -1 & -1 & 175 & 3 & 10 & 1 & 1,661 \\
\hline 9 & -1 & -1 & -1 & 155 & 3 & 10 & 1 & 1,515 \\
\hline 10 & $-1,682$ & 0 & 0 & 150 & 4 & 20 & 4 & 3,399 \\
\hline 11 & $+1,682$ & 0 & 0 & 185 & 4 & 20 & 4 & 3,645 \\
\hline 12 & 0 & $-1,682$ & 0 & 165 & 2 & 20 & 4 & 3,399 \\
\hline 13 & 0 & $+1,682$ & 0 & 165 & 6 & 20 & 4 & 3,645 \\
\hline 14 & 0 & 0 & $-1,682$ & 165 & 4 & 3 & 1 & 0,045 \\
\hline 15 & 0 & 0 & $+1,682$ & 165 & 4 & 35 & 4 & 3,997 \\
\hline 16 & 0 & 0 & 0 & 165 & 4 & 20 & 4 & 4,023 \\
\hline 17 & 0 & 0 & 0 & 165 & 4 & 20 & 4 & 4,023 \\
\hline 18 & 0 & 0 & 0 & 165 & 4 & 20 & 4 & 4,023 \\
\hline 19 & 0 & 0 & 0 & 165 & 4 & 20 & 4 & 4,023 \\
\hline 20 & 0 & 0 & 0 & 165 & 4 & 20 & 4 & 4,023 \\
\hline & 0 & 0 & 0 & 165 & 4 & 20 & 4 & 4,023 \\
\hline
\end{tabular}

Regression coefficients:
$\mathrm{b}_{0}=4.023$
$\mathrm{db}_{0}= \pm 0.020$
$\mathrm{b}_{0}$ - significant
$b_{1}=0.073$
$\mathrm{db}_{1}= \pm 0.014$
$b_{1}$ - significant
$b_{2}=0.073$
$\mathrm{db}_{2}= \pm 0.014$
$b_{2}$ - significant
$b_{3}=1.175$
$\mathrm{db}_{3}= \pm 0.014$
$b_{3}$ - significant
$b_{12}=0.125$
$\mathrm{db}_{12}= \pm 0.018$
$b_{12}$ - significant
$b_{13}=-0.125$
$\mathrm{db}_{13}= \pm 0.018$
$b_{13}$ - significant
$b_{23}=-0.125$
$\mathrm{db}_{23}= \pm 0.018$
$b_{23}$ - significant
$b_{11}=-0.177$
$\mathrm{db}_{11}= \pm 0.013$
$b_{11}$ - significant
$b_{22}=-0.177$
$\mathrm{db}_{22}= \pm 0.013$
$b_{22}$ - significant
$b_{33}=-0.708$
$\mathrm{db}_{33}= \pm 0.013$
$b_{33}$ - significant 
All regression coefficients of the equation are significant and the response equation is shown below "Eq.(1)".

$$
\begin{aligned}
y=4.023+0.073 x_{1}+0.073 x_{2}+ & 1.175 x_{3}+0.125 x_{1} x_{2}-0.125 x_{1} x_{3}-0.125 x_{2} x_{3}-0.177 x_{1}^{2} \\
& -0.177 x_{2}^{2}-0.708 x_{3}^{2}
\end{aligned}
$$

The analysis of the mathematical model suggests that the resultant variable $y$ of the print adhesion depends on each of the factors $x_{1}, x_{2}, x_{3}$ independently, as well as on the interactions $X_{i}^{*} X_{2} ; X_{i}^{*} X_{3} ; X_{2}{ }^{*} x_{3}$. By checking the coefficient significance with the Student test, it is observed that all the coefficients of the equation are significant. Given the above component of the model, it proves to be adequate, because the calculated value of the Fisher - Snedecor test is lower than the tabulated value of the same test, Ftab $=5.050$.

The analysis of the response equation coefficients, which models the variation of the print adhesion obtained by thermal transfer, leads to the following conclusions:

1) the linear part of the equation contains all three parameters, which shows that their variation significantly influences the resultant;

2) the increase of the values $x$, (temperature), $x_{2}$ (pressure) and $x_{3}$ (pressing time) leads to the increase of the resultant value with a stronger / considerable influence from the factor $x_{3}$ (pressing time);

3 ) it is found that $x$, and $x_{2}$ change the result by $1.81 \%, x_{3}$ changes the result by $29.21 \%$, the influence of the factor $x_{3}$ the pressing time is approximately 16 times greater than the factors $x_{1}$ (temperature) and $x_{2}$ (pressure);

4) the quadratic part contains all the terms, it participates in the increase of the resultant with significant values that reverse the order of influence indicated by the linear part; that means it remains as a variation of $x_{1}$ (temperature) and $x_{2}$ (pressure) to produce a balanced decrease of the result $y$ (print adhesion) with the variation speed $4.40 \%$, while the factor $x_{3}$ (pressing time) leads to the decrease of the result with a speed of $17.60 \%$; 5) the interactions $x_{1}{ }^{*} x_{2}$ follow the direction which the individual variation of each of the variables $x_{1}$ and $x_{2}$ has upon the resultant $y$ (print adhesion), so it is positive, but the interactions $x_{2}{ }^{*} x_{3}$ and $x_{1}{ }^{*} x_{3}$ diminish the value of the resultant. All interactions have balanced influence.

The graphical representations resulted from the OPTEX program, which also served to obtain mathematical models. The graphs are shown in Figures 1 - 3.
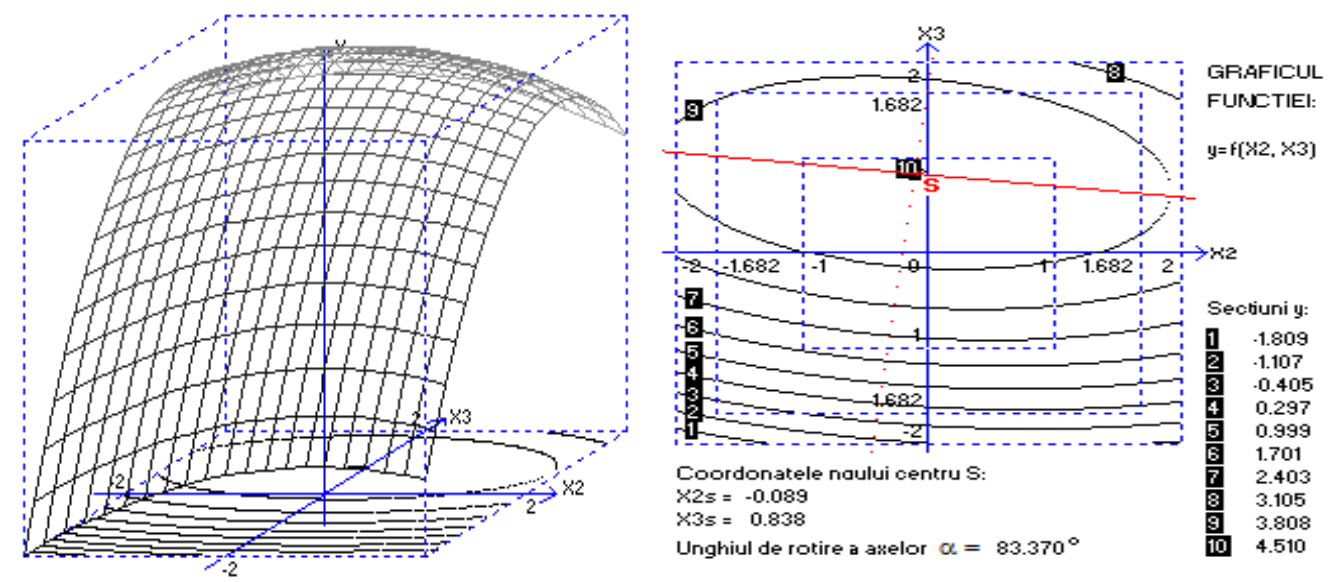

Figure 1. Variation of print adhesion $(y)$ as a function of pressure $\left(x_{2}\right)$ and pressing time $\left(x_{3}\right)$, (temperature $x_{1}=0$ ). 

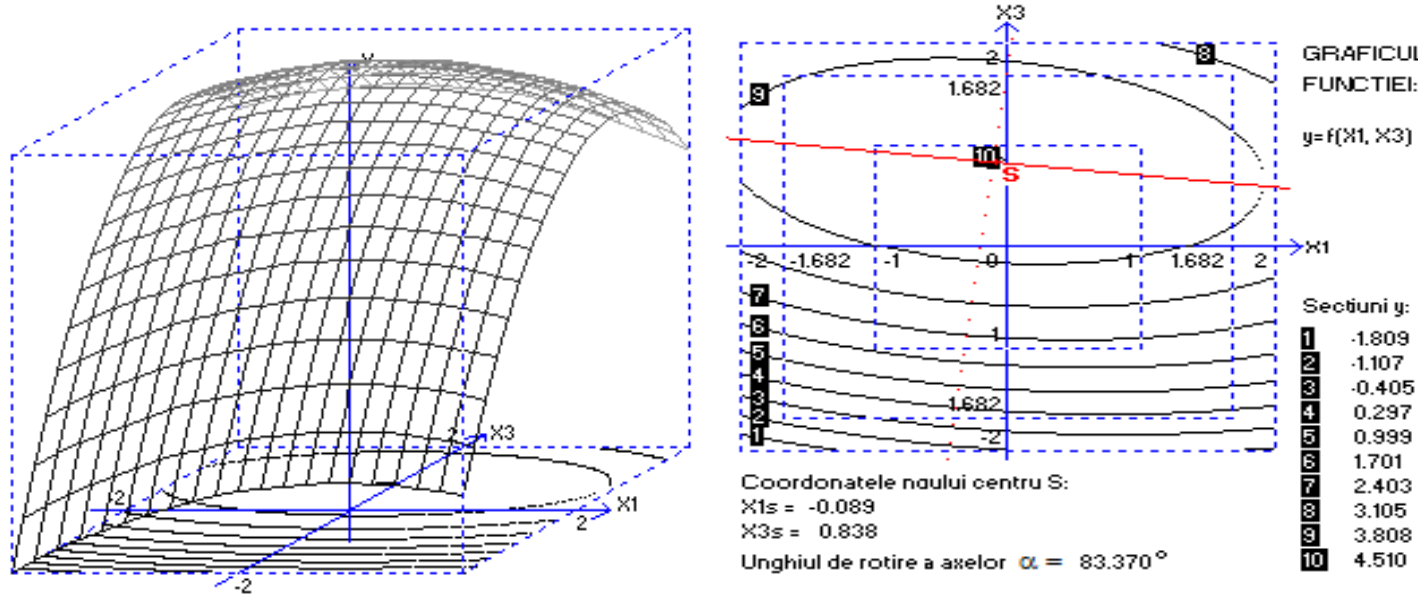

Figure 2. Variation of adhesion $(y)$ as a function of temperature $\left(x_{1}\right)$ and pressing time $\left(x_{3}\right)$, (pressure $\left.\mathrm{x}_{2}=0\right)$.
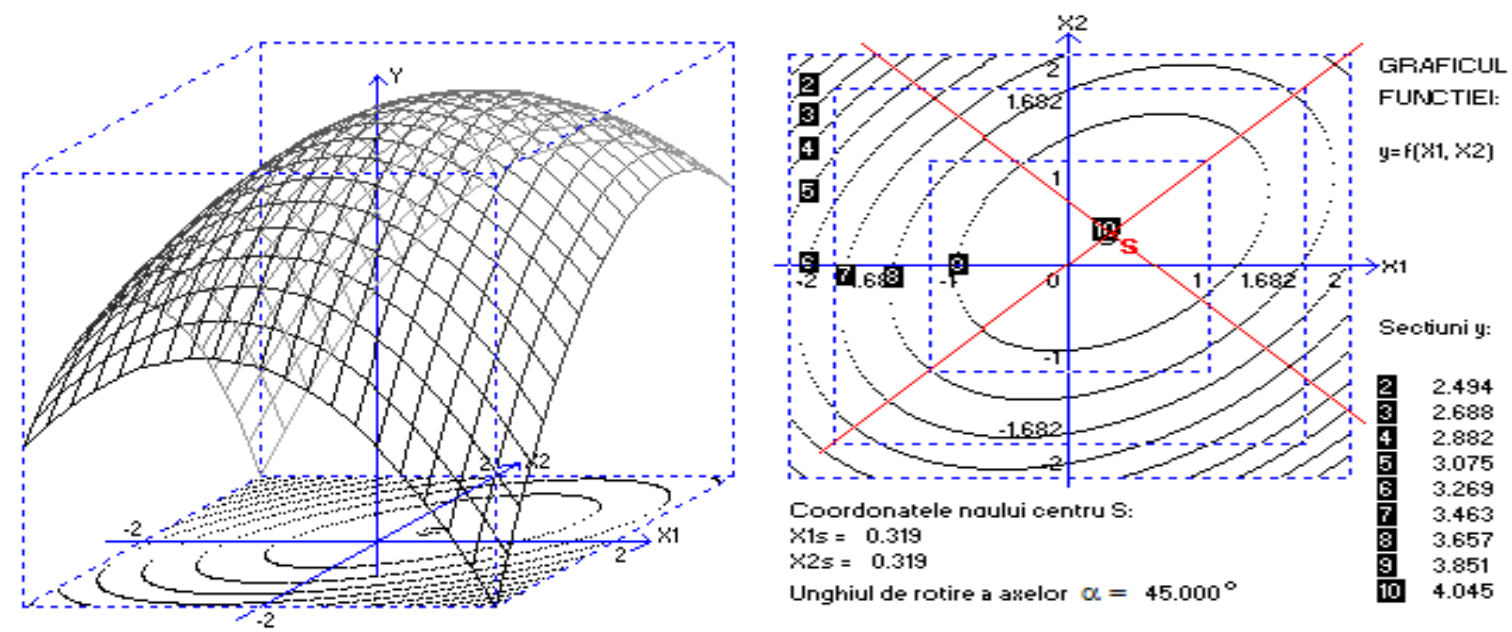

Figure 3. Variation of print adhesion $(y)$ as a function of temperature $\left(x_{1}\right)$ and pressure $\left(x_{2}\right)$, (pressing time $x_{3}=0$ ).

For the independent variables, in order to facilitate the interpretation and realization of the graphs, the coded values were used, and for the isocurves the real values of the result were used. Experimental data were obtained for each resultant variable on the three types of textile material.

The analysis of the graphical representations of the response surface that models the variation of the adhesion of the print as a function of temperature, pressure and pressing time leads to the following conclusions:

1) the response surface is of elliptical paraboloid type with extreme maximum point located in the experimental region; the constant level curves obtained by sectioning the response surface with constant level planes are ellipses or ellipse arcs;

2) the projection of the top of the paraboloid in the $x_{1}$ and $x_{2}$ plane represents a maximum point.

The results for the following textile material: fabric from $86 \%$ PA + 14\% EA and 100\% PA fabric, with membrane Gore-Tex are presented below.

Textile material type: Fabric from 86 \% PA+14 \% EA

The regression equation "Eq.(2)". 


$$
\begin{array}{r}
y=1.996+0.319 x_{1}+0.343 x_{2}+0.759 x_{3}+0.125 x_{1} x_{2}+ \\
.125 x_{1} x_{3}+0.375 x_{2} x_{3}+0.012 x_{1}{ }^{2}-0.165 x_{2}^{2}+0.012 x_{3}^{2}
\end{array}
$$

Findings from the analysis of the mathematical model:

By checking the significance of the coefficients with the Student test, it is observed that all the coefficients of the equation are significant.

The model proves to be adequate, because the calculated value of the Fisher - Snedecor test is less than the tabulated value of the same test, Ftab $=5,05$.

The analysis of the response equation coefficients leads to the following conclusions:

- Linear part of the equation contains all the parameters which shows that their variation significantly influences the resultant;

- Increasing the values of $x_{1}$ (temperature), $x_{2}$ (pressure) and $x_{3}$ (pressing time) leads to increasing of the resultant value with a stronger influence from the factor $x_{3}$ (pressing time);

- $\quad \mathrm{x}_{1}$ modifies the answer by $15.98 \%, \mathrm{x}_{2}$ modifies the answer by $17.18 \%, \mathrm{x}_{3}$ modifies the answer by $38.03 \%$, the influence of the factor $x_{3}$ (pressing time) is approximately double compared to the factors $\mathrm{x}_{1}$ (temperature) and $\mathrm{x}_{2}$ (pressure);

- It participates in the increase of the result with significant values that keep the order of influence indicated by the linear part, only for the factor $\mathrm{x}_{2}$ there is an influence decrease;

- So, the variation of $x_{1}$ (temperature) and $x_{3}$ (pressing time) to produce a balanced positive change of the resultant $y$ with the rate of variation $0.6 \%$, while the factor $\mathrm{x}_{2}$ (pressure) leads to the decrease of the resultant with a speed of $8.27 \%$;

- Interactions $x_{1}{ }^{*} x_{2}, x_{2}{ }^{*} x_{3}, x_{1}{ }^{*} x_{3}$ respect the meaning that the individual variation of each of the variables $x_{1}, x_{2}$ and $x_{3}$ influences the resultant $y$ (print adhesion) positively, with a 3 times greater influence from interaction $x_{2}{ }^{*} x_{3}$;

Findings from the analysis of response areas:

The response surface is of ascending ridge type, without extreme points, the constant level curves obtained by sectioning the response surface with constant level planes are parabolic arcs, due to the fact that the center of the surface is far from the center of the experiment area, the curvature radius of the surface in the experimental area is very large and is represented by a tendency of its surface portion to change according to plan.

Textile material type: Fabric 100 \% PA, with membrane Gore- Tex

The regression equation "Eq.(3)":

$$
y=1.989+0.539 x_{1}+0.393 x_{2}+0.685 x_{3}+0.250 x_{2} x_{3}+0.054 x_{1}^{2}+0.054 x_{2}^{2}+0.054 x_{3}^{2}
$$

Findings from the analysis of the mathematical model:

- The linear part of the equation contains all three parameters, which shows that their change significantly affects the result;

- An increase in the values of $x_{1}$ - temperature, $x_{2}$ (pressure) and $x_{3}$ (pressing time) leads to an increase in the resulting value with a stronger influence of the factor $x_{3}$ (pressing time);

- It was found that $x_{1}$ changes the answer by $27,1 \%, x_{2}$ changes the answer by $19,76 \%, x_{3}$ changes the answer by $34,44 \%$;

- $\quad$ The quadratic part contains all the terms and participates in increasing the result with significant values that support the order of influence indicated by the linear 
part; so, variation in $\mathrm{x}_{1}$ (temperature), $\mathrm{x}_{2}$ (pressure) and $\mathrm{x}_{3}$ (pressing time) leads to a balanced positive change in the resultant y (print adhesion) with a rate of change of $2.71 \%$;

- The interaction $x_{2}{ }^{*} x_{3}$ takes into account the value that an individual change in each of the variables $x_{2}$ and $x_{3}$ has for the resulting $y$ (print adhesion), that is, it is positive.

Findings from the analysis of response areas:

The response surface is of the "minimax" type (hyperbolic paraboloid), the center of the surface is the $S$ point. The $S$ point is outside of the experimental area; the constant level curves for the quasi-stationary domain are hyperbolic; the coefficients of the canonical equation have the same signs, and the constant level curves are balanced in the $x_{2}$ and $x_{3}$ direction, because the influence of these two variables is balanced.

\section{Conclusion}

Following the analysis of the mathematical models obtained and the response surfaces, it was found that the influence of the pressing time factor is approximately double compared to the temperature and pressure factors. So, time is a key factor that must be initially taken into account when setting technological parameters.

The recommended parameters for each textile material are:

For the fabric made of $100 \%$ polyamide fibers (PA) with Gore-Tex membrane the recommended technological parameters are: temperature $=185^{\circ} \mathrm{C}$; exerted pressure $=4$ atm; exposure time of the part under press $=35 \mathrm{~s}$.

For the fabric made of $86 \%$ polyamide fibers $(P A)$ and $14 \%$ elastane (EA) the recommended technological parameters are: temperature $=150{ }^{\circ} \mathrm{C}$; exerted pressure $=6 \mathrm{~atm}$; exposure time of the part under press $=35 \mathrm{~s}$.

For knitwear made of 59\% polyimide fibers (PA) and $41 \%$ elastane (EA) the recommended technological parameters are: temperature $=150{ }^{\circ} \mathrm{C}$; exerted pressure $=2 \mathrm{~atm}$; exposure time for the part under press $=35 \mathrm{~s}$.

\section{References}

1. Fărîmă D.. Balan S., Irovan M., Tutunaru I. Comfort and performance in sports. lasi: „Performantica”, 2007. [in Romanian].

2. Introduction to textiles in sportswear. In book: Textiles in sportswear Edition: 1st Publisher: Elsevier/woodhead Publishing Editors: Roshan Shishoo, May 2015, DOI: 10.1016/B978-1-78242-229-7.00001-1

3. Pratima Chowdhury, Kartick K. Samanta, Santanu Basak. Recent Development in Textile for Sportswear Application. In: International Journal of Engineering Research \& Technology (IJERT) Volume 03, Issue 05 (May 2014), Disponible: https://www.ijert.org/recent-development-in-textile-for-sportswear-application [accesed 20/08/2020]

4. Michaela Nusser, Veit Senner High - Tech - Textiles in Competition Sports. In: Conference of the International Sports Engineering Association (ISEA). Procedia Engineering 2 (2010) 2845-285; Disponible: https://core.ac.uk/download/pdf/81119772.pdf [accesed 22/08/2020]

5. Koncar V. Smart Textiles and Their Applications. Cambridge: Woodhead Publishing, 2016.

6. Dubina N. Printing on textiles. [online]. Disponible: http://compuart.ru/article/23905, [accesed 05/08/2021] [in Russian].

7. Mihăilescu B. Excellence in the production of heat transfer foils. In: Polygraphic Business Journal, 2017, No. 229 - june, - pp. 38-40.

8. Ungureanu C. Special effects on textiles by heat transfer. In: Polygraphic Business Journal, 2018, No. 241 August, pp. 40 - 41. [in Romanian].

9. Bismark Sarkodie, Benjamin Tawiah, Christiana Agbo, Jakpa Wizi. Status and Development of Transfer Printing in Textiles-A Review // March 2018, AATCC. In: Journal of Research 5(2):1-18, DOI: 10.14504/ajr.5.2.1 
10. Fernand Schlaeppi. Present and Future Developments in Transfer Printing. In: First Published March 1, 1977 Research Article https://doi.org/10.1177/004051757704700309

11. Griffiths J., Jones F. Scientific Aspects of Transfer Printing. October 2008, In: Coloration Technology 93(5):176 - 185. DOI:10.1111/j.1478-4408.1977.tb03340.x

12. Patent: Heat transfers with minimal transfer marking on performance fabrics. Inventors: Chiao YI-HUNG, Liviu Dinescu, Andrew SPENDLOVE, Johannes YTTRI, Osman N.TANRIKULI, Ben T. O'BRIEN, Disponible: https://patents.google.com/patent/WO2015103098A1/en [accesed 15/08/2021]

13. Sandra Stojanović, Jelka Geršak, Dušan Trajković, Nenad Ćirković. Influence of sublimation transfer printing on alterations in the structural and physical properties of knitted fabrics. In: Coloration Technology, Volume 137, Issue 2, April 2021, Pages 108-122. https://doi.org/10.1111/cote.12508

14. https://www.siser.com/products/

15. Ciocoiu M. Statistical-mathematical bases of analysis and quality control in the textile industry. Iași: In: Performantic, 2002. [in Romanian].

16. Irovan M., Tutunaru I., Farima D., Ciocoiu M. Software Application for Mathematical Modelling of Technological Process in Textile Industry. In: Annals of the University of Oradea. "Fascicle of Textiles, Leatherwork". Published by Editura Universităţii din Oradea VOLUME XIX, 2018, No. 2, ISSN 1843 - 813X, p.5560 http://textile.webhost.uoradea.ro/Annals/Contents\%2020.html 